\title{
7 The mining struggle in El Salvador and the role of the Catholic Church
}

\author{
Andrés McKinley
}

In the middle of the sixteenth century, when King Ferdinand of Spain was orienting his men on the priorities for the conquest of the new world, his instructions were clear and concise: "Get the gold, humanely if possible; but, at any cost, get the gold" (Perlez and Johnson 2005, n.p.). Five hundred years later, following in the footsteps of the conquistadores, transnational mining corporations from Canada, the United States, Australia, and as far away as Russia, are coming to Central America in search of gold, silver, iron, nickel, and other valuable metals in a mineral belt extending from Panama to Mexico.

In an effort to win the hearts and minds of governments and local communities, these corporations promise new technologies which, they claim, protect the environment, utilizing terms like "modern mining" or "responsible mining." They promise jobs and an economic boom for poor and desperate communities located near mineral deposits. They assure a significant increase in government income which can then be used to support health, education, and other national priorities, and promise respect for basic human rights. In spite of this enormously attractive offer, the people of El Salvador said "no."

Public opinion polls carried out by the Jesuit-run Central American University (UCA) in 2007 and 2015 demonstrated a massive rejection of metallic mining by affected communities and broad sectors of Salvadoran society. In $2015,79.5 \%$ of those polled considered El Salvador to be an inappropriate place for metallic mining. Over $76 \%$ expressed opposition to potential mining projects in their municipality and $77 \%$ demanded that the government take immediate measures to prohibit metallic mining. Through the work of UCA and informed and steadfast support from the country's episcopal leadership, the Catholic Church was one of the leading forces for translating that widespread concern about mining into national policy for the common good of the people. In what follows, I will describe the main reason why El Salvador's people rejected mining: water. I will then outline the country's history of resistance to mining and analyze why it ultimately proved successful. Finally, I will address the distinct and central role played by the Catholic Church in this struggle.

DOI: $10.4324 / 9781003094272-7$ 


\section{Why El Salvador said "no" to metallic mining}

How can one understand the radical position against mining taken by the citizens and the Catholic Church of a small impoverished country in dire need of direct foreign investment, jobs, and better services in health and education? The answer to this question can be summarized in a single word: water.

El Salvador suffers from a severe crisis in terms of quantity, quality, and access to water. The crisis has its origins in decades of mismanagement, overexploitation, and contamination. Recent studies indicate that if the country does not make profound changes in how it manages water resources, life in El Salvador will be unviable within eighty years (Agencia EFE 2016). And the situation continues to worsen. In April of 2019, the Ministry of Environment and Natural Resources (MARN) gave a dismal account of the prospects for freshwater availability over the first three months of the rainy season (May-July). This prediction was based on the findings of the recent Central America Climate Forum in which rain patterns were analyzed and compared with previous years. In its report, MARN revealed that the average water flows of several of the most strategic rivers in the country would show a deficit of between $45 \%$ and $60 \%$ between the months of May and July. The Huiza, Chilama, and Amayo rivers, in the province of La Libertad in central El Salvador, would reduce their water flows by up to $50 \%$. In the eastern part of the country, the Goascorán river in the province of La Unión, the Torola river in the department of Morazán, the Rio Grande in San Miguel, and the Molino and Cacao Rivers of Usulután would be reduced by more than $60 \%$. Finally, in the western zone, the flow levels of the Angue, San José, and Ostúa Rivers of Metapán in the province of Santa Ana would see reductions of $45 \%$.

According to MARN, aquifers around the country are also being gradually depleted by climate change and overexploitation by large-scale agriculture and industry. The impact has been dramatic, with rural communities suffering from decreases in water availability in natural springs and wells, and with aquifers that supply potable water to important urban centers reaching worrisome levels. Aquifers supplying water to the capital city of San Salvador suffered a decrease of 4.23 meters between 2012 and 2019. The aquifers supplying water to the eastern city of San Miguel suffered a similar decrease (4.14 meters) between 2014 and 2019, and the aquifer of San Agustín-San Francisco Javier in the southern city of Usulután recorded a decrease of 4.44 meters between 2013 and 2019 (Calderón 2019). According to the government's National Administration of Aqueducts and Sewers, no less than 45 wells providing potable drinking water for 2.1 million people in greater San Salvador were depleted between 2008 and 2016, and water levels in remaining wells are diminishing at a rate of between 


\section{Andrés McKinley}

1 and 1.5 meters per year (Machuca 2019). Adding to the crisis, environmentalists have reported that over $90 \%$ of surface waters suffer from some degree of contamination (La Prensa Gráfica 2016).

These developments have led highly respected international experts like the UN Economic Commission for Latin America and the Caribbean, the Latin American Water Tribunal, and the Global Water Partnership to declare that El Salvador is on the threshold of water stress, a situation in which freshwater resources available for human use decline to a level of 1,700 cubic meters per person per year, rendering it impossible to meet demand. MARN, for its part, warns that by 2022, $80 \%$ of El Salvador's national territory will suffer from water stress (Agencia EFE 2019).

Metallic mining requires enormous quantities of freshwater. One can say that freshwater is the lifeblood of mining in the same way that it is the lifeblood of human existence. Mining competes with local communities, and with humanity at large, for this vital liquid. The average gold mine in Central America utilizes more than a million liters of water per day. Some mines in the region utilize more than 6 million liters per day, and larger mines around the world utilize hundreds of millions (McKinley 2016, i, 21). Metallic mining, especially for gold, also contaminates water. The separation of gold from ore requires sodium cyanide, a toxic chemical that can be lethal in quantities smaller than a grain of rice. Cyanide solutions frequently seep into freshwater sources in and around mining sites, or escape from poorly constructed tailings dams where toxic waste from the mining process is stored (24-25). Cyanide also evaporates at $36^{\circ} \mathrm{C}$, contaminating the air in a radius of many miles around mining operations.

Apart from sodium cyanide, metallic mining utilizes explosives, fuel, antifreeze, and other materials that leave toxic residues that seep into freshwater systems. The most problematic source of water pollution from metallic mining, however, is a process called acid mine drainage, a phenomenon that occurs when rock with high sulfide content (commonly found in Central America) is extracted from the earth, crushed, and exposed to oxygen from air and rainwater, which converts the sulfides into sulfates and, finally, into sulfuric acid. The sulfuric acid, as well as other harmful metals that it leaches from the walls of the mine and rocks in the surrounding area, flows into nearby streams, aquifers, and other freshwater sources. Acid mine drainage is a difficult process to reverse and can be found today in gold mines in France and Spain that date to the time of the Roman Empire (Rodriguez, Garcia, and Castillo 2007, 33).

Given these factors, it is obvious that a country like El Salvador-on the brink of water stress, with high levels of pollution, the highest population density in the western hemisphere, and already suffering from severe water shortages-is not an appropriate location for large-scale metallic mining. 


\section{The national struggle against metallic mining}

The struggle against metallic mining in El Salvador lasted for over seventeen years and evolved through four clear and distinct phases.

Phase 1 (2000-2004) was marked by the incursion of transnational mining companies and the growing resistance of local communities. This phenomenon was especially clear in the northern provinces of Chalatenango and Cabañas, regions highly impacted by the civil war of 1980-1992. In the case of Chalatenango, the communities most threatened by mining were well-organized and committed to protecting their territories, considered sacred and drenched in the blood of family members assassinated by the army during the war. These communities were quick to respond to the presence of foreign mining companies prospecting for gold and silver, and they built strong local processes of resistance.

The case of Cabañas was more complex. The communities in this province had been polarized by the war, with ex-combatants from guerrilla organizations living side by side with former soldiers or collaborators with the army. They were engaged in a painful search to heal the wounds of twelve years of war and mend the social fabric of their communities. Different opinions about mining exacerbated existing divisions and hindered local resistance. Nevertheless, the province, like Chalatenango, remained predominantly anti-mining.

Phase 2 (2005-2009) was characterized principally by the formation and consolidation of a national struggle against metallic mining based on the logic of public policy advocacy. This initiative began in 2005 with the organization of a broad coalition, the National Roundtable on Metallic Mining in El Salvador (MESA), consisting of community-based organizations, development NGOs, environmentalists, church groups, legal aid organizations, and other actors. MESA, strongly supported by Oxfam America and other international organizations, quickly became the backbone of the struggle. It employed a rights-based focus, promoted concrete policy proposals, and designed and applied well-planned advocacy campaigns to advance its policy agenda.

Phase 3 (2009-2016) was dominated principally by a prolonged legal struggle which began with a promise by President Antonio Saca in 2009 that no new permits for mineral exploration or licenses for exploitation would be approved by his government. This policy, also adopted by the two following administrations, amounted to a de facto moratorium on mining in the country. In response, a Canadian mining corporation, Pacific Rim, and a US mining corporation, Commerce Group, brought lawsuits against El Salvador in the World Bank's International Center for Settlement of Investment Disputes (ICSID), accusing the Salvadoran government of violating its own investment law and investor protection clauses of the Central American Free Trade Agreement. 


\section{Andrés McKinley}

Lawsuits have become increasingly common, according to a recent report by the Institute for Policy Studies, Mining Watch Canada, and the Center for International Environmental Law (Moore and Rocha 2019). The report analyzes a growing trend of multimillion-dollar claims brought by the mining industry against Latin American governments struggling to defend the environment and, in particular, freshwater resources. In 2009, however, this tactic was a new and powerful threat to the anti-mining movement of El Salvador. The country eventually won both cases, though the Pacific Rim case lasted seven years. The cases cost the Salvadoran state over eight million dollars in legal fees, monies that were urgently needed for healthcare, education, public security, and other priorities. With the finalization of the ICSID ruling, Pacific Rim and its new owner, OceanaGold, were ordered to reimburse this amount to the state. OceanaGold finally complied under continuous pressure from anti-mining advocates.

Phase 4 (2016-2017) saw the final and definitive battles for prohibition. With the Archdiocese of San Salvador and UCA taking the lead, the Catholic Church of El Salvador assumed a central role. This phase culminated in a ban on metallic mining in the country. The particular role that Catholic actors played in this process is detailed below.

\section{Components of success}

The national struggle against metallic mining in El Salvador was launched in highly unfavorable circumstances. El Salvador was governed at the time by a right-wing pro-business political party that prioritized direct foreign investment in its strategies for economic growth. The communities most threatened by mining had little experience with this industry and knew little about the costs to the environment and traditional livelihoods. The Salvadoran population in general had little awareness of the importance of natural resources, especially water, for the future viability of the country and was being aggressively bombarded by propaganda campaigns of transnational mining corporations highlighting the purported benefits of metallic mining.

Nevertheless, the struggle took root and grew, transforming itself into a national movement with the slogan "Yes to Life, No to Mining." Small-scale organizational and educational initiatives in local communities grew into a broad-based national campaign for legislative reform which eventually accumulated sufficient influence to shift the balance of power in Salvadoran society and force policymakers to prioritize national interests. The strategic vision that guided the struggle included several key components that distinguished the process from other antimining battles in the region, and contributed in important ways to the final victory. 


\section{Nonviolence}

El Salvador is a country with a long and tragic history of violence, beginning with the Spanish conquest and followed by over three hundred years of brutal colonization, fifty years of repressive military dictatorship, and twelve years of bloody civil war. The country remains highly polarized in social, economic, and political terms, and highly susceptible to violence in the face of continuing social inequities and unresolved issues at the local and national levels. It was not surprising, therefore, when pro-mining interests in the country turned violent in 2009, resulting in the assassination of five antimining activists from the provinces of Cabañas, where the Canadian mining company Pacific Rim was insisting, at all costs, on mining gold and silver.

Pacific Rim also mobilized its workers and a group of local activists in aggressive street demonstrations against the Archdiocese of San Salvador, Oxfam America, and the Office of the Human Rights Ombudsperson, all of which opposed metallic mining. Within this highly volatile context, however, the organizers and key activists of the struggle in El Salvador insisted that it be one of ideas, not brute force; they believed in the power of truth, of objective scientific data, to overcome the aggression and well-financed propaganda campaigns of the transnational mining corporations.

\section{Linkage between local communities and national movements}

A second important feature was linking local community resistance to national advocacy campaigns, recognizing that the struggles of the poor at the local level are rarely sustainable if they are isolated from national processes. At the same time, it was understood that national campaigns are less viable and meaningful when they fail to incorporate the aspirations, motivations, and determined social force of broad-based community participation.

\section{The methodology of public policy advocacy}

A third key feature was the application of public policy advocacy methodologies. These non-violent processes were designed to influence policymakers via clear and precise proposals. This meant that the struggle could not be limited to street protests but had to include a clear policy agenda and well-planned advocacy campaigns designed to move that agenda forward. It was a disciplined effort by an organized citizenry to influence the formulation, approval, and implementation of public policies, programs, and practices through persuasion and social pressure.

\section{A logic of empowerment}

The struggle in El Salvador also focused on empowerment. Since public policy advocacy was considered to be an exercise of citizen power, 
advancing a policy agenda of prohibition required the empowering of key actors, especially communities most threatened by metallic mining. Far from being an abstract concept, empowerment meant organizing and educating communities and civil society at large and building alliances to enhance their capacity to influence legislators. It meant building and preserving unity; preparing strong, democratic, and well-informed leadership; assuring gender equity; building technical skills to access, analyze, and utilize information; generating knowledge through research; and building capacity for formulating viable policy goals and for developing the planning and negotiating skills essential to attaining policy victories.

\section{A variety of strategies and tactics}

A fifth feature of the struggle was the application of a wide variety of strategies and tactics. Among these were organizing and alliance-building, education and awareness-raising, research, lobbying, communications and media, and mobilization.

In practice, this meant traveling to distant communities to provide workshops, inform leadership, and organize. It meant building alliances at the national and international levels to include communities and key actors from El Salvador, other Central American nations, and countries that were home to transnational mining companies, especially the United States, Canada, and Australia. It meant holding public forums to inform citizens from all sectors of society, developing and disseminating educational materials, conducting public opinion polls and disseminating the results, lobbying government (including the presidency) and policymakers, working with the media to educate and inform public opinion, promoting popular consultations in municipalities threatened by mining, accompanying legislators on visits to former mining sites where environmental destruction from metallic mining continues to destroy freshwater resources and traditional livelihoods, and, of course, taking to the streets in periodic demonstrations.

\section{The special role of the Catholic Church}

It should be no surprise that the Catholic Church of El Salvador played a key role in the struggle. Since the early 1970s, Vatican documents have spoken of how unregulated human activity has caused a planetary ecological crisis. In his 1971 apostolic letter, Octogesima Adveniens, Pope St. Paul VI $(1971, \mathbb{} 21)$ referred briefly to the environmental challenges of the time, pointing out that:

Man is suddenly becoming aware that by an ill-considered exploitation of nature he risks destroying it and becoming in his turn the victim of this degradation ... This is a wide-ranging social problem which 
concerns the entire human family. The Christian must turn to these new perceptions in order to take on responsibility, together with the rest of men, for a destiny which from now on is shared by all.

Pope St. John Paul II touched on this theme in 1979 in Redemptor Hominis. $\mathrm{He}$ called attention to worsening environmental problems and the need for conversion to remedy these, which would require enormous changes in lifestyles, models of production, and consumption (\$15-16). In 2007, Pope Benedict XVI called for an end to the structural causes of environmental decline, including predominant models for economic growth that have shown themselves to be a threat to the environment and to life itself. And in 2015, Pope Francis presented his powerful encyclical, Laudato Si, the first encyclical in the history of the Catholic Church to focus exclusively on the environment. In this document, Francis calls on the world's population to care for our common home by defending the environment and curtailing the abuse of natural resources, especially water. Like his predecessors, he criticizes systemic causes of environmental deterioration, pointing specifically to unbridled capitalism, a system that prioritizes capital over human life, generating inequity and imbalance between North and South and placing life itself at risk. Finally, he calls for a new ecological culture, with a different perspective and with policies and educational programs that lead to a new spirituality and a different way of life.

Many Catholics in El Salvador-Saint Oscar Romero, Father Rutilio Grande, the 1989 UCA martyrs, and many others-have been killed for actively living in solidarity with the poor and accompanying them in their struggles for social justice. Because of this history, the Catholic Church has enormous credibility and influence within Salvadoran society. It was a natural ally in the struggle against metallic mining because that struggle was grounded in the principles of Catholic social teaching, including respect for human dignity, respect for human life, free association, citizen participation, a preferential option for the poor and vulnerable, solidarity, and stewardship.

As early as the year 2000, Bishop Eduardo Alas Alfaro of Chalatenango opposed the incursion of transnational mining corporations in the communities of his diocese. In 2007, the Episcopal Conference of El Salvador formally pronounced its opposition to metallic mining with a document entitled "Cuidemos la Casa de Todos" ("Take Care of our Common Home"), arguing that:

Our small country is the space in which God the Creator has called us to life. This is the portion of the world that He has entrusted to us to care for and to use according to His will ... But this blessed land that we dearly love suffers from growing and unmerciful deterioration. We are all responsible for conserving and defending it because the environment is the home of us all: of this and of future generations. (n.p.) 
In February 2009, Monsignor José Luis Escobar Alas was installed as Archbishop of San Salvador. In his inaugural message, with elections upcoming and the country's president and the presidents of the legislature and judiciary all in attendance, the new Archbishop said: "To the departing government as well as the incoming government, whatever party you are from, I call upon you to prohibit the mining of precious metals. I ask this due to the grave damage it would cause to the health of our people through the contamination of our water" (Moreno 2009, n.p.). In the following years, Archbishop Escobar Alas has spoken out continually against metallic mining in press conferences, which are traditionally held after the main Sunday mass in the National Cathedral, and in other forums. His auxiliary bishop, Cardinal Gregorio Rosa Chavez, has done the same.

As the struggle grew in El Salvador, the persistent messaging of Pope Francis in defense of the environment motivated and strengthened the resolve of the Salvadoran Catholic bishops, priests, nuns, and laity to take on this cause with increasing emphasis and determination. Pope Francis called upon his church to be in the street, dirtied and tattered by its accompaniment of traditionally marginalized peoples. This call had an enormous impact on the hierarchy of El Salvador.

The commitment and role of the Salvadoran Church took a strategic leap in 2016 with the formulation of a new proposal for prohibition developed by legal experts and environmental specialists at UCA. It was not the first bill to be presented to the National Assembly: MESA presented one in 2006 and another was presented in 2013, but right-wing parties representing the interests of big business and closely linked to transnational corporate interests refused to debate either bill. The UCA proposal was shared with Archbishop Escobar Alas, who immediately gave it his support, and on February 6, 2017, UCA authorities presented it to the Commission on Environment and Climate Change of the Legislative Assembly, Archbishop Escobar Alas, Cardinal Rosa Chavez, and representation from the General Office for Justice, Peace and Integrity of Creation of the Franciscan Order.

By early March, 2017, the bill had barely advanced in the Assembly commission, so Archbishop Escobar Alas and other Catholic leaders called for a massive demonstration on March 9 (Velásquez 2017). Over six thousand priests, nuns, and laypeople, together with other social movements, responded to the call and marched from a park in the center of the capital city to the Legislative Assembly. There, in the presence of national and international media, we were met by representatives of each of the political parties. During the meeting that ensued, the president of the Legislative Assembly promised that the new bill would be approved before Easter Sunday, which was still several weeks away. Given the accumulated frustrations of seventeen years of organizing and struggle, few of the participants left the meeting convinced that the promise would be kept.

In the days that followed, transnational mining corporations like OceanaGold began to perceive that the balance of power was shifting. 
Recognizing the growing threat to their interests, they returned to their earlier strategies of trying to win hearts and minds through aggressive media campaigns filled with promises of new technologies which would be more harmonious with the environment and would make "responsible mining," as they called it, possible. When they chose as their model their gold and silver mine in the province of Nueva Vizcaya, Philippines, little did they know how ready the experts of UCA were to rebut that claim.

Fully aware of the environmental destruction and human rights violations associated with gold mining in the Philippines, UCA invited the governor of Nueva Vizcaya to visit El Salvador and planned a week of public forums and meetings with communities, the President of El Salvador and his cabinet, and, most importantly, the Legislative Assembly's Commission on Environment and Climate Change, which was also being intensely lobbied by OceanaGold. Using visual evidence of the destruction caused by OceanaGold in his province, the governor made convincing arguments against metallic mining. His 26 years as a political leader in his own country gave him great credibility with Salvadoran legislators and, in particular, the members of the Commission on Environment and Climate Change. Already highly knowledgeable about metallic mining as a result of receiving educational materials and direct testimony from UCA and other social actors over the years, the Commission members took the governor's presentation as a closing argument on the issue and voted to approve the Church/UCA proposal for the prohibition of metallic mining. On the following day, March 29, the bill was sent to the plenary session of the Legislative Assembly, where it was approved without opposition.

\section{Conclusion}

With the approval of this bill, El Salvador became the first country in the world to ban this controversial industry. Suffering from an abundance of negative superlatives (most violent nation, most densely populated, most deteriorated environment, most deforested, most water-stressed) this small nation became a precedent-setting example of citizen resolve, Catholic social action, national pride, and environmental protection, giving hope to communities and countries around the world who are confronting the abuses and violations of transnational mining corporations.

The long and difficult struggle to attain this once unthinkable goal was a gradual process consisting of several accumulating factors in which the Catholic community played a role:

- Social force bred by constructing and consolidating a social movement and empowering key social actors to analyze the threat of metallic mining, identify policy solutions, design specific policy proposals, and advance their political agenda through public policy advocacy; 
- Knowledge about the vulnerable situation of El Salvador's environment and the threat generated by metallic mining;

- Power to influence policymakers via lobbying, disseminating educational materials, and organizing and mobilizing increasingly broad sectors of society;

- Alliances at the local, national, and international levels that enlightened public opinion via effective communication and media strategies;

- Broad-based consensus among different sectors of society through dialogue with opponents and prioritizing national interests over individual and party interests; and

- Political will among decision makers to defend the environment.

The victory against metallic mining in El Salvador surprised and angered transnational companies and left them determined to dismantle this historic policy victory. The failure of the Salvadoran government to fully comply with the law two years after its approval is another serious problem. According to the law, by March 2019, small-scale artisanal mining, given a two-year grace period while communities searched for alternative livelihoods, should have been curtailed. Inactive mines around the country should have been adequately closed and environmental damage caused by mining activities in earlier decades should have begun to be remedied. None of this has occurred.

Nevertheless, public opinion and the will of lawmakers remain staunchly in favor of prohibition. More importantly, the struggle itself, with its emphasis on citizen empowerment and the application of methodologies of public policy advocacy instead of brute force, has offered a new way of doing politics in El Salvador that will hopefully consolidate this victory, strengthen an incipient democracy, transform traditional power relationships within society, and contribute to more profound and sustainable social change in El Salvador.

\section{References}

Agencia EFE. 2016. "La vida en El Salvador será inviable en 80 años por la crisis de agua, dice un estudio." May 12, 2016. https://www.efe.com/efe/america/ sociedad/la-vida-en-el-salvador-sera-inviable-80-anos-por-crisis-de-agua-dice-unestudio/20000013-2923438.

Agencia EFE. 2019. "El 80\% del territorio salvadoreño estará en 'estrés hídrico' en el año 2022." March 22, 2019. https://www.efe.com/efe/america/sociedad/el-80del-territorio-salvadoreno-estara-en-estreshidrico-ano-2022/20000013-3932816.

Benedict XVI. 2007. Letter to the Ecumenical Patriarch of Constantinople on the Occasion of the Seventh Symposium of the Religion, Science and the Environment Movement. September 1, 2007. http://www.vatican.va/content/benedict-xvi/en/ letters/2007/documents/hf_ben-xvi_let_20070901_symposium-environment.html.

Calderón, Beatriz. 2019. "Poco favorables perspectivas hidrológicas para El Salvador: menos agua subterránea y disminución en caudales de ríos en próximos 
tres meses." La Prensa Grafica, May 2, 2019. http://www.laprensagrafica.com/ elsalvador/Poco-favorables-perspectivas-hidrologicas-para-El-Salvador-menosagua-subterranea-y-disminucion-en-caudales-de-rios-en-proximos-tres-meses20190502-0295.html.

John Paul II. 1979. Redemptor Hominis. http://www.vatican.va/content/john-paulii/en/encyclicals/documents/hf_jp-ii_enc_04031979_redemptor-hominis.html.

La Prensa Gráfica. 2016. "90\% de aguas superficiales del país están contaminadas.” March 21, 2016. https://www.laprensagrafica.com/elsalvador/90--de-aguassuperficiales-del-pais-estan-contaminadas-20160321-0079.html.

Machuca, Evelyn. 2019. "45 pozos de la ANDA en el AMSS dejaron de producir agua entre 2008 y 2016.” La Prensa Grafica, March 22, 2019. https:// www.laprensagrafica.com/elsalvador/45-pozos-de-la-ANDAen-el-AMSS-dejaronde-producir-agua-entre-2008-y-2016-20190321-0550.html.

McKinley, Andrés. 2016. La Amenaza de La Minería Metálica En Un Mundo Con Sed. San Salvador: UCA Editores. https://www.uca.edu.sv/iudop/wpcontent/uploads/La-Amenaza-de-la-Mineri\%c3\%aca-Meta \%c3\%aclica-en-unMundo-con-Sed.pdf.

Moore, Jen, and Manuel Perez Rocha. 2019. "Extraction Casino: Mining Companies Gambling with Latin American Lives and Sovereignty through Supranational Arbitration." Mining Watch Canada, Institute for Policy Studies, and Center for International Environmental Law. https://miningwatch.ca/sites/ default/files/isds_report_final_.pdf.

Moreno, Nestor Ivan. 2009. "Una Nueva Luz, un Nuevo Arzobispo...y el Pueblo De Dios." La Voz de los Sin Voz. February 20, 2009. https://pueblodedios. wordpress.com/2009/02/.

Paul VI. 1971. Octogesima Adveniens. http://www.vatican.va/content/paul-vi/en/ apost_letters/documents/hf_p-vi_apl_19710514_octogesima-adveniens.html.

Perlez, Jane, and Kirk Johnson. 2005. "Behind Gold's Glitter: Torn Lands and Pointed Questions." New York Times, October 24, 2005. Accessed from Global Policy Forum, April 21, 2021. http://www.globalpolicy.org/socecon/tncs/2005/ 1024ring.htm.

Rodriguez, Roberto, Cristobal Garcia, and Efrain Castillo. 2007. "El Carácter Intermitente y Permanente Del Drenaje Ácido de Minas (AMD) En Zonas Semiáridas.” Ingenieria 2, no. 2: 33-36.

University Public Opinion Institute. 2015. "Opinions and Perceptions towards Metals Mining in El Salvador." University of Central America - José Simeón Cañas Newsletter 29, no. 2. https://www.uca.edu.sv/iudop/wp-content/uploads/ Press-Release.pdf.

Velásquez, Eugenia. 2017. "Ley contra la minería con respaldo en la Asamblea Legislativa." ElSalvador.com. March 9, 2017. https:/historico.elsalvador.com/ historico/317744/ley-contra-la-mineria-con-respaldo-en-la-asamblea-legislativa.html. 